\title{
EVALUASI PROGRAM PEMBINAAN PRESTASI OLAHRAGA BOLA VOLI PADA SMK NEGERI DI KOTA BENGKULU
}

\author{
Yunita Candrawati \\ Penjas fkip unib, e-mail: yunitacandrawati@gmail.com \\ Sugiyanto \\ Universitas Bengkulu \\ Bogy Restu Ilahi \\ Universitas Bengkulu
}

\begin{abstract}
Abstrak
Penelitian ini bertujuan untuk mendeskripsikan Evaluasi Program Pembinan Prestasi Olahraga Bola Voli pada SMK Negeri Di Kota Bengkulu. Subjek dalam penelitian ini adalah Pembina, Pelatih, Atlet SMK Negeri 1, SMK Negeri 3, SMK Negeri 5, SMK Negeri 7 Kota Bengkulu. Pengumpulan data dan Instrumen penelitian ini berupa kuesioner/angket yang sudah divalidasi oleh ahli. Analisis data dalam penelitian ini menggunakan analisis data kualitatif dan keabsahan data statistik yang menggunakan rumus persentase. Hasil penelitian dalam pembahasan menunjukan bahwa hasil Evaluasi Program Pembinaan Prestasi Olahraga Bola Voli Pada SMK Negeri Di Kota Bengkulu belum seluruhnya maksimal dalam pelaksanaannya dari 4 sekolah yang diteliti hanya 1 sekolah yang menjalankan program pembinaan dengan baik. Hal tersebut dilihat dari segi manajemen pengelolaan sarana dan prasaranan yang sangat minim, pengelolaan dana yang belum tersalurkan menyeluruh untuk kegiatan program pembinaan tersebut, serta kurangnya dukungan dari pihak sekolah. Kurang maksimalnya program latihan yang diberikan pelatih, membuat tujuan pencapaian prestasi puncak tidak dapat terlaksana dengan baik. Kesimpulan dari program pembinaan belum maksimal dari segi prasarana, pengelolaan dana, serta dukungan dari sekolah dari 4 sekolah yang di teliti hanya $25 \%$ sekolah yang sudah melaksanakan program dengan baik.
\end{abstract}

Kata Kunci: Evaluasi, Program Pembinaan Prestasi, Bola Voli

\begin{abstract}
This study aimed to describe the Evaluation of the Achiefment Volley Ball Training Program at Vocational School in Bengkulu City. The subject of this study is trainerss, coachers, atlhetes of SMKN 1, SMKN 3, SMKN 5, SMKN 7 Bengkulu city. Dt colection and instrumen of the study is kuestionnaire which has been validated by expert. Data analisis oif this study used kualitative data analysis and statistic data validity used percentage the result of this study showed that the of grall result of the evaluation of the achievement volly ball training program at vocational school in Bengkulu city are not maximal yet in the implementation. from 4 school are studied, there is only one school which implement development program well. It can be seen from the lact of the good mnagement of facilities and infrastructure, the management of the found whish is not distributed yet for the development program, and the lact of support from school. Since the lack of training program from coachers, it makes the aim program of the peak achievement cannot be implemented well. The conclution of this
\end{abstract}


study is dhat the development program is not running well in mangement of facility and infrastructures, management from school. From 4 schools are studied, there is only 25\% which has implemented the development program well.

Keywords: Evaluation, Achiefment Training Program, Volley Ball

\section{PENDAHULUAN}

Olahraga merupakan bagian dari
aktivitas sehari-hari manusia yang berguna untuk membentuk jasmani dan rohani yang sehat. Pencapaian prestasi puncak dalam olahraga hanya dapat dicapai melalui proses pembinaan yang sistematik, terencana, teratur dan berkesinambungan. Pembinaan prestasi club olahraga di SMK Negeri merupakan tolak ukur di mana akan tumbuh dan berkembang bibit-bibit yang berprestasi dan dapat menjuarai event olahraga. Di harapkan pembinaan prestasi atlet di SMK Negeri dapat mengatasi permasalahan atlet di Kota Bengkulu yang belum mencapai prestasi yang maksimal. Dalam hal ini kita ketahui bersama bahwa prestasi olahraga bola voli pada sekolahsekolah menengah kejuruan maupun sokolah lainnya kurang dalam penerapannya hal ini terjadi dikarenakan minimnya atau terbatasnya sarana dan prasarana, program latihan, fasilitas yg sangat mendukung program pembinaan olahraga tersebut.

\section{Dalam penelitian ini dapat} dirumuska masalah sebagai berikut; Bagaimanakah evaluasi program pembinaan prestasi olahraga bola voli pada SMK Negeri di Kota Bengkulu ?. 1. Adapun tujuan dari penelitian ini adalah Merupakan sarana utama untu mengetahui segala sesuatu yang ada dalam penelitian, sesuai dengan judul skripsi yang peneliti kemukakan. 2. Untuk mengetahui program pembinaan prestasi olahraga bola voli pada SMK Negeri di Kota Bengkulu.

\section{METODE}

Metode penelitian ini adalah menggunakan metode kualitatif. Metode yang di gunakan adalah survey yaitu pengumpulan data di lapangan. Dalam penelitian kualitatif instrumennya adalah orang atau human instrument, yaitu peneliti itu sendiri. Penelitian evaluasi ini menggunakan salah satu model evaluasi yaitu model CIPP (conteks, input, prosess, dan product) dan teknik pengumpulan datanya menggunakan dokumentasi dan kuisioner. Penelitian ini mengambil obyek penelitian seluruh yang berhubungan dengan judul penelitian yaitu, Program Pembinaan Prestasi Olahraga Bola Voli Pada Kota Bengkulu. Mengambil subyek dalam penelitian ini menggunakan teknik purposive, yaitu dengan memilih orangorang yang di anggap tahu tentang fokus masalah seperti pihak yang terkait dengan pengambilan keputusan, atlet, pembina atau pengurus dan pelatih program latihan atlet bola voli di SMK Negeri Kota Bengkulu.

Teknik dan instrumen yang di gunakan untuk mengumpulkan informasi dalam penelitian evaluasi dapat dilakukan dengan berbagai setting. Pada penelitian ini teknik pengumpulan data yang peneliti gunakan yaitu, teknik pengamatan observasi, kuesioner, dan studi dokumentasi. Teknik analisis data merupakan hal yang sangat penting dalam penelitian karena teknik analisis data yang digunakan harus jelas dan diarahkan untuk menjawabrumusan masalah yang berguna dalam memecahkan masalah penelitian. Aktivitas dalam analisis data, 
yaitu : data reduction, data display, dan conclusion.

\section{HASIL DAN PEMBAHASAN}

\section{Evaluasi Proses Pembinaan}

Berdasarkan hasil penelitian yang telah dilakukan dengan menggunakan metode observasi dan angket/kuesioner mengenai proses pembinaan prestasi bola voli bahwa proses pembinaan yang berlangsung di SMK Negeri 1, 3, 5, 7 Kota Bengkulu sekarang ini sudah menjalankan program pembinaan jangka panjang untuk meningkatkan prestasi atlet baik tingkat daerah maupun tingkat nasional,walaupun dalam pelaksanaannya belum secara keseluruhan berjalan sesuai dengan yang diinginkan. Atlet tidak selalu di berikan bonus setiap mereka menang dalam sebuah pertandingan, akan tetapi bagi atlet yang berprestasi ke tingkat nasional maka mereka akan mendapatkan reward dari sekolah tersebut, reward tersebut misalnya berupa bebas bayar uang spp. Tahap pembinaan pada SMK Negeri di Kota Bengkulu belum seluruhnya mengarah pada tahapan latihan spesialisasi. Sehingga masih sangat sulit untuk meningkatkan pencapaian prestasi yang maksimal.

Kurang adanya dukungan-
dukungan mengakibatkan pembina,
pelatih, dan atlet menjadi sedikit patah
semangat untuk melaksanakan program-
program latihan.

Evaluasi Program Pembinan

Berdasarkan hasil penelitian yang telah dilakukan dengan menggunakan metode observasi dan angket/kuesioner mengenai program pembinaan prestasi bola voli bahwa program pembinaan yang berlangsung di SMK Negeri 1, 3, 5, 7 Kota Bengkulu sekarang belum semuanya memiliki program latihan yang terstruktur dan tercana dengan baik. Program yang dijalankan sudah mengarah, pelatih selalu menciptakan suasana latihan yang kondusif serta membuat situasi latihan yang menyenangkan.

Program latihan yang dijalankan bertujuan untuk meningkatkan kemampuan fisik dan kemampuan bermain bola voli atlet tersebut. Tidak semua pelatih yang ada di SMK Negeri selalu datang tepat waktu. Pelatih selalu meningkatkan kedisplinan para atlet, pelatih juga memberikan sanksi kepada atlet yang datang terlambat. Untuk menambah semangat atlet dalam bertanding pelatih selalu mendampingi para atlet pada event pertandingan bola voli, tanpa kecuali pelatih ada kepentingan yang tidak bisa ditinggalkan. Jadwal latihan dalam masing-masing sekolah berbeda-beda. SMK Negeri 1 melaksanakan program latihan dalam setiap minggunya berlangsung 4 kali, (selasa, rabu, jumat, sabtu untuk putri), ( senin, selasa, kamis, jumat untuk putra). SMK Negeri 3 hanya menjalankn program latihan 1 kali dalam setiap minggunya, kegiatan itu berlangsung pada hari sabtu, dan pada hari itu juga jadwal latihan putra-putri berlangsung. Pada SMK Negeri 5 hanya menjalankan program latihan 1 kali dalam setiap minggunya, kegiatan itu berlangsung pada hari kamis, dan pada hari itu juga jadwal latihan putra-putri berlangsung. Dan SMK Negeri 7 hanya menjalankn program latihan 1 kali dalam setiap minggunya, kegiatan itu berlangsung pada hari rabu, dan pada hari itu juga jadwal latihan putra-putri berlangsung.

Evaluasi Manajemen

Program pembinaan olahraga bola voli pada SMK Negeri 1, 3, 5, 7 Kota Bengkulu sekarang berjalan dengan baik, program pembinaan bola voli memiliki 
struktur organisasi, struktur oraganisasi tersebut melibatkan komite dan orang tua. Struktur organisasi tersebut memiliki susunan, seperti program pelatih dan atlet yang cukup jelas.

Dalam pelaksanaan program pembinaan prestasi di SMK Negeri masing-masing memiliki pembina dan pelatih, SMK Negeri 1 ada 5 pelatih 2 peltih putri 3 pelatih putri, SMK Negeri 3 memiliki 1 pelatih untuk putra dan putri. SMK Negeri 5 juga hanya memiliki 1 pelatih untuk putra dan putri. SMk Negeri 7 juga 1 Pelatih putra dan putri.

Pengelolaan sarana dan prasarana, sarana dan prasarana yang ada di SMK Negeri 1, 3, 5, 7 Kota Bengkulu secara keseluruhan belum terpenuhi dengan baik, hanya ada berapa sekolah yang memang sudah benar-benr baik untuk melaksankan program pembinaan. Seharusnya sarana dan prasarana harus terpenuhi dengan baik, agar proses program pembinaan dapat berjalan dengan baik dan dapat meningkatkan prestasi yang maksimal.

Pengelolaan Dana, dana untuk keperluan kegiataan program pembinaan bola voli di SMK Negeri 1, 3, 5, 7 Kota Bengkulu berasal dari pihak sekolah, dalam kegiatan program pembinaan ini ada anggaran dana setiap tahunnya untuk memperbaiki fasilitas dan kegiatan operasional lainnya. Tetapi dari ke 4 sekolah yang diteliti secara keseluruhan belum tersalurkan sesuai dengan yang diharapkan. Hal tersebut terlihat dari minimnya fasilitas yangb ada pada sekolah tersebut.

\section{Evaluasi Prestasi}

Berdasarkan hasil pengisian angket atlet dan data prestasi, dari ke 4 sekolah yang diteliti hanya SMK Negeri 1 yang memiliki pencapain prestasi yang maksimal. Untuk SMK Negeri 3, 5, 7 mereka dalam 3 tahun terakhir ini tidak pernah menyumbangkan prestasi di bidang bola voli, hal tersebut terjadi karena kurangnya program latihan yang maksimal dalam pencapain prestasi puncak.

\section{Pembahasan}

Berdasarkan uraian dari hasil penelitian bahwa Contek, Input, Proses, Produk untuk 4 sekolah yang diteliti. SMK Negeri 1 dari segi Contek, Input, Proses, Produk secara keseluruhan sudah berjalan dengan sangat baik. Untuk SMK Negeri 3 dari segi Contek sudah cukup baik, akan tetapi dari segi input, proses, produk secara keseluruhan belum berjalan dengan baik. Untuk SMK Negeri 5 dari segi Contek sudah cukup baik, akan tetapi dari segi input, proses, produk secara keseluruhan belum berjalan dengan baik. Dan SMK Negeri 7 saat ini juga dari segi Contek sudah cukup baik, akan tetapi dari segi input, proses, produk secara keseluruhan belum berjalan dengan baik.

\section{PENUTUP}

\section{SIMPULAN}

Berdasarkan dari hasil penelitian dan pembahasan yang diperoleh, maka dapat disimpulkan sebagai berikut :

Proses Program Pembinaan Prestasi Olahraga Bola Voli pada SMK Negeri di Kota Bengkulu dapat dikatakan baik dan maksimal apabila komponen-komponen yang berkaitan dengan pembinaan prestasi, dan program pembinaan prestasi sudah berjalan dengan baik.

Baik atau tidaknya program pembinaan olahraga bola voli dapat dilihat dari hasil pencapaian prestasi secara maksimal ditingkat daerah, provinsi, maupun tingkat nasional. 
Bebrapa faktor yang menjadi pelaksanaan kegitan program pembinaan olahraga bola voli tersebut antara lain ialah sebagai berikut, kurangnya fasilitas atau sarana dan prasarana yang memadai, kurangnya dukungan dari pihak sekolah, orang tua, pelatih serta pengurus, belum tersalurkannya pendanaan secara menyeluruh, program latihan yang belum maksimal, belum terarah dan belum secara spesialisasi.

Dari hasil penelitian dan pembahasan bahwa SMK Negeri yang ada di Kota Bengkulu belum seluruhnya melaksanakan program pembinaan secara maksimal dan sesuai dengan arah tujuan pencapain prestasi yang maksimal. Dari 4 SMK Negeri di Kota Bengkulu yang sudah diteliti hanya 1 sekolah yang melaksanakan program pembinaan olahraga bola voli secara sistematik, terencana, teratur, dan berkesinambungan, untuk tujuan pencapaian puncak prestasi yang maksimal.

\section{DAFTAR PUSTAKA}

Ahmadi, Ruslam.(2014). Metodologi Penelitian Kualitatif. Yogyakarta:Ar-ruzz Media

Apta Mylsidayu,dkk. (2015). Ilmu Kepelatihan Dasar. Bandung:Alfabeta.

Edwan, Ari, dan Bogy. 2017. "Pengaruh Metode Latihan Plyometric Terhadap Kemampuan Jumping Smash Bola Voli Siswa Ekstrakurikuler SMPN 1 Bermani Ilir Kabupaten Kepahiang" Jurnal Kinestetik, Vol. 1 (1).
Ferdiansah, Rahmad.(2017).Analisis Pemb inaan Prestasi Klub Sepak Bola Usia Dini Kota Bengkulu.S1 Skripsi. Fakultas IImu Pendidikan

Harsono.(1988). Coaching dan Aspekaspek Psikologis dalam coaching. Jakarta: CV Tambak Kusuma

Harsuki.(2012). Pengantar Manajemen Olahraga. Jakarta: PT RajaGrafindo Persada

Irmansyah, Johan.(2015). Evaluasi Program Pembinaan Prestasi Cabang Olahraga Bola Voli Pantai di Provinsi Nusa Tenggara Barat dan Daerah istimewa Yogyakarta

Joko Priono, dkk. (2014). Evaluasi Program Pembinaan Bola Voli Remaja Asahan di Pengkab PBVSI Kabupaten Asahan Provinsi Sumatera Utara

Pitaloka, Septi Rizki.(2017). Implementasi Pembinaan Klub Bola Voli Usia Dini Di Sekolah Dasar Kota Bengkulu. S1 Skripsi. Fakultas Ilmu Pendidikan

Setywan, Andy Riki.(2010). Pembinaan Prestasi Olahraga Bola Voli di Klub Bola Voli Kmc Kabupaten Pemalang

Subroto, Toto.(2003).Pembelajaran Permainan Bola Voli. Jakarta:Depdiknas

Sudjana.(1992). Pengantar Manajemen Pendidikan Luar Sekolah. Bandung: Nusantara Pres 